\title{
Impact of educational program about care of children with febrile convulsion on nurses' knowledge and performance
}

\author{
Faransa A. Ahmed ${ }^{1}$, Ahmed E. Saad ${ }^{2}$, Shimaa A. Khalaf $* 3$ \\ ${ }^{1}$ Pediatric Nursing, Faculty of Nursing, Assiut University, Assiut, Egypt \\ ${ }^{1}$ Pediatric Medicine, Faculty of Medicine, South Valley University, Qena, Qena, Egypt \\ ${ }^{3}$ Community Health Nursing, Faculty of Nursing, Assiut University, Assiut, Egypt
}

Received: May 9, 2016

Accepted: July 10, 2016

Online Published: August 28, 2016

DOI: 10.5430/jnep.v7n1p79

URL: http://dx.doi.org/10.5430/jnep.v7n1p79

\begin{abstract}
Background and objective: A febrile (fever) convulsion is a fit or seizure that occurs in children with fever. The key responsibilities of the nurse are to protect the child from injury during seizure and assist in the treatment of the underlying cause. The objective of this study is to determine the impact of educational program on nurses' knowledge and performance.

Methods: Design: Quasi-experimental research design. Subjects and methods: 44 nurses who working at Assiut Children Hospital. Tools: A structured interview sheet and observational check list.

Results: Statistically significant difference between nurses' knowledge and practices after post-test and follow-up.

Conclusions: The nurses' knowledge regarding care of child with febrile seizure were not enough with some unsafe practices. The study recommended On Job Training (OJT) programs are suggested in order to refresh and update nurses' knowledge.
\end{abstract}

Key Words: Nurses, Pediatric febrile seizures, Convulsions, Febrile convulsion and seizure disorders

\section{INTRODUCTION}

Febrile Convulsion (FC) is a type of seizures specifically in infancy and childhood. FC is associated with fever and occurs usually between the age 6 months and 6 years that shows no evidence of intracranial infection or defined other causes. ${ }^{[1]}$ There are different types of FC. Convulsions with fever have three explanations: (1) An infection of C.N.S; (2) Seizure disorders in which the initial seizures are triggered by the stress of fever, although subsequent seizures may be a febrile; (3) A simple febrile seizure. ${ }^{[2]}$

FC is believed to be genetically determined and maternal inheritance is an important factor. Eighty percent of monozy- gotic twins are concordant for $\mathrm{FC}$ and siblings of patients with epilepsy are at increased risk of FC. ${ }^{[3]}$ The most common extracranial sources of fever in cases of FC are upper respiratory tract infection, otitis media, pneumonia, influenza, gastroenteritis, or urinary tract infection. ${ }^{[4]}$

The exact degree of temperature at which FC occur is not exactly known, but usually develops when the temperature reaches $39^{\circ} \mathrm{C}$ or greater especially if there is rapid rise of temperature. ${ }^{[5]}$ Simple FC is defined as a single brief $(<15$ minutes) generalized seizures occurring during the rapid rise of temperature with a brief post-ictal period of drowsiness. ${ }^{[6]}$ Complex febrile (atypical FC) is prolonged (> 15 minutes),

\footnotetext{
* Correspondence: Shimaa A. Khalaf; Email: shiamaa.abdelrahim@yahoo.com; Address: Community Health Nursing, Faculty of Nursing, Assiut University, Egypt.
} 
focal or multiple during the same illness or with prolonged postictal drowsiness. ${ }^{[7]}$ The risk of developing unprovoked seizures is increased by several factors; neurodevelopmental anomalies, complex febrile seizures, recurrent FC, brief duration of fever before initial seizures, and family history of epilepsy. ${ }^{[8]}$

The main aim of the investigations is to determine the cause of the fever and to exclude intracranial infection, the history and examination may suggest an obvious source of fever such as an otitis media, pharyngitis, pneumonia, gastroenteritis, or urinary tract infection which should be confirmed by urine culture. ${ }^{[3]}$

Blood cell counts, measurements of glucose, calcium, electrolytes, and urine analysis are not cost effective and can be done according to the circumstances of every case. EEG should be performed on every infant who presented with abnormal neurological examination or with positive family history of epilepsy. CT and MRI are indicated in focal convulsions with focal deficits even transitory following a seizure. ${ }^{[9]}$

The treatment of FC is controversial. Prophylactic antiepileptic drugs don't appear to be effective in preventing FC Phenobarbital has been recommended in the past but is no more effective than Placebo and the drug has detrimental effect on cognitive and intellectual development in children. Rectal Diazepam, given at the onset of febrile episode, has been recommended to prevent febrile seizures in susceptible children. ${ }^{[10]}$

In case of febrile convulsion the nurse must reduce the fever by bringing the child's fever down as quickly as possible, remove the child's clothing and apply cold washcloths to the face and neck. If the seizure persists, sponge the rest of the body with cool water. When the convulsion is over and the child is awake, the nurse must give the usual dose of oral fever-reducing medicines (as doctors order's) for the child's weight and age, gradual monitoring for body temperature, and encourage the child to drink cool fluids. ${ }^{[11]}$

\subsection{Significance of the study}

During the researcher's work in the neurology and reception units at the Assiut Children Hospital, it has been observed that nurses need to improve their knowledge and performance regarding caring for child with febrile convulsion. So, developing an intervention program will improve nurses' knowledge and performance.

\subsection{Aim of the study}

This study aimed to determine the impact of educational program about febrile convulsion care on nurses' knowledge and performance at Assiut Children Hospital.

\subsection{Research questions}

- What were the nurses known about febrile convulsion?

- In what way nurses deal with child having febrile convulsion?

\section{SUBJECTS AND METHODS}

The purpose of this chapter is to discuss the research methodology and procedures including the description of the research hypothesis, design, setting, sample, tools, procedure and data analysis.

\subsection{Research design}

Quasi-experimental research design was used to conduct this study. This design is the same as the classic controlled experimental design except that the subjects cannot be randomly choose. The most common quasi-experimental design is the comparison group Pre-test/Post-test design.

\subsection{Setting}

The present study was carried out in the neurology \& reception units at Assiut Children Hospital. Neurology unit contains from 2 patient rooms, each room has 8 beds and intensive care room have 8 beds. Reception unit contains 8 patient rooms, each room have 5 beds and intensive care room have 8 beds.

\subsection{Subjects}

The current study included all the available (44) nurses, which consisted from (9) baccalaureate and (35) secondary school degree who working in neurology \& reception units at Assiut children Hospital.

\subsection{Tools of the study}

Two different tools were used to collect study data. These are knowledge test, and an observation checklist.

Tool I: A designed structured interview form was developed by the researcher after reviewing the relevant literature and related studies to collect data for this study. It consisted of two parts.

The first part: Personal and socio-demographic data sheet. It included data about study subjects such as age, marital status, qualification, job position, years of experience, current job experience and previous attendance of training courses. The second part involved the following data. It was developed by the researcher based on related literatures and studies. It was used to assess nurses' knowledge about febrile convulsion care. This part included questions about febrile convulsion such as definition, causes, classification, signs and symptoms, 
febrile convulsion precautions and nursing care during and after febrile convulsion.

Tool II: Observation Check list. A checklist, sometimes called a tick chart, is an inventory of behaviors or skills that the observer marks or checks if the pupil is seen to demonstrate them. This tool covered the performance of the study subjects. It included especially design observation checklist form was developed by the researcher to assess the performance of the nurses. This tool was used before and after the program to evaluate the effectiveness of the training program on the nurses' performance while using educational model.

The observation checklist included the following procedures:

- Nurses' performance as regards to nursing role during febrile convulsion.

- Nurses' performance as regards to nursing role after febrile convulsion.

- The same tools was used immediately after implementation of the program (immediate post-test), in addition to three months later to evaluate the gain of knowledge after the intervention.

\subsection{Study method}

\subsubsection{Preparatory phase and administrative design}

- An official letter approval was obtained from the Dean of Faculty of Nursing, Assiut University to the Director of Assiut Children Hospital.

- This letter included a permission to carry out the study and explain the purpose and nature of the study.

\subsubsection{Pilot study}

A pilot study was carried out before starting data collection on three nurses chosen randomly who was excluded from the sample. The aim of pilot study is to test the clarity, applicability of tools and to estimate the time required to fill the questionnaire. Based on the pilot study, the necessary modifications in the sheet were done.

\subsection{Ethical consideration}

The purpose of this study was explained for every individual that include Director of the Neurology \& Reception Units and subjects of the study sample. Nurses have ethical rights to participate or refuse participation in the study. Consent to participate in the study was written from director and oral from nurses, informed them that the information obtained would be confidential and used only for the purpose of the study.

\subsection{Validity}

The validity of the study tool was assessed to check the relevance, coverage, and clarity of the questions by a jury panel

Published by Sciedu Press of professors from five expert pediatric fields.

\subsection{Reliability}

Reliability was estimated by Alpa Cronbachs test for study.

\subsection{Results of the test}

Knowledge scale $=0.851$; Practice scale $=0.883$; Total $=$ 0.819 .

\subsection{Practical work}

Data was collected in the period from first of April to the end of the July at first; the researcher assessed the nurses' needs before the program through an interview questionnaire and follow up 3 months for post-test after program directly.

The study was carried out in three phases:

Phase 1: Identification of the training needs for the nurses through:

- Assessment of nurses knowledge about febrile convulsion such as definition, causes, classification, signs and symptoms, febrile convulsion precautions and nursing care during and after febrile convulsion.

- Assessment of nurse's performance by using the observation check-list. This was conducted by the researcher in the neurology \& reception units at Assiut Children Hospital. Care taken that the nurses were not recognized that.

Phase 2: Educational program

(1) Design a training program according to nurse's needs.

(2) Develop and implement an educational program meeting the nurses need regarding to the care of febrile convulsion.

(3) Develop an educational booklet to the nurses to provide them with needed information for caring of child with FC (definition of FC, different types, nursing care, etc.).

Table 1 shows the plan of the educational program.

- General objective of the educational training health program. Improve knowledge and performances of nurses regarding caring of child with FC.

- Teaching time: The time of teaching sessions started at $8 \mathrm{pm}$ during the night shift.

- Teaching place: The program conducted at Assiut Children Hospital

Phase 3: Evaluate the degree of improvement for the nurse's knowledge and performance by using immediate post-test for knowledge and performance at 3 months after the program. An interview was conducted for nurses on an individual basis. 


\subsection{Scoring system}

\subsubsection{Assessment of nurses' knowledge}

To assess the knowledge of nurses regarding seizure disorders and care of child with seizure, a scoring system was applied, one score was given for each correct answer and zero for incorrect answer. The maximum total score for knowledge was 50 divided as follows:

- Knowledge concerning the disease scored 22.
- Knowledge concerning nursing role during seizure scored 14.

- Knowledge concerning nursing role after seizure scored 2.

- Knowledge concerning indication for calling E.M.S. scored 7.

- Knowledge concerning seizure's precautions scored 5.

Table 1. Time table of the educational program for nurses regarding FC

\begin{tabular}{|c|c|c|c|}
\hline $\begin{array}{ll} & \text { Session } \\
\end{array}$ & Contents & Method of teaching and Media & Evaluation \\
\hline First day/session I: 2 hs & $\begin{array}{l}\text { Orientation } \\
\text { - Definition of FC } \\
\text { - The different types of FC }\end{array}$ & $\begin{array}{l}\text { - Brainstorming } \\
\text { - Discussions } \\
\text { - Handout }\end{array}$ & $\begin{array}{l}\text { Posttest } \\
\text { questionnaire }\end{array}$ \\
\hline Second day/session II: 2 hs & $\begin{array}{l}\text { - Causes of FC } \\
\text { - When FC can be fatal } \\
\text { - Preventive measures for child at risk for FC }\end{array}$ & $\begin{array}{l}\text { - Brainstorming } \\
\text { - Discussions } \\
\text { - Handout }\end{array}$ & $\begin{array}{l}\text { Posttest } \\
\text { questionnaire }\end{array}$ \\
\hline Third day/session III: 2 hs & $\begin{array}{l}\text {-Diagnosis and treatment of FC } \\
\text { - Nursing care before FC } \\
\text { - Nursing care during FC } \\
\text { - Nursing after FC }\end{array}$ & $\begin{array}{l}\text { - Brainstorming } \\
\text { - Discussions } \\
\text { - Handout } \\
\text { - Role play } \\
\text { - Simulation }\end{array}$ & $\begin{array}{l}\text { Posttest } \\
\text { questionnaire } \\
\text { Observational } \\
\text { checklist }\end{array}$ \\
\hline Fourth day/session V: 2 hs & $\begin{array}{l}\text { - Revision } \\
\text { - Post-test }\end{array}$ & $\begin{array}{l}\text { - Brainstorming } \\
\text { - Discussions } \\
\text { - Handout }\end{array}$ & $\begin{array}{l}\text { Posttest } \\
\text { questionnaire }\end{array}$ \\
\hline
\end{tabular}

\subsubsection{Assessment of nurses' performance}

To assess the performance of nurses regarding care of child with seizure, scoring system was applied, one score was given for each item done correctly and zero for each incorrect and/or not done item. The maximum total score for performance was 16 divided as follows:

- Nurses' performance during seizure scored 14;

- Nurses' performance after seizure scored 2.

The total score of either knowledge or performance of nurses was judged as follows: Each question have correct answer = 1 or incorrect $=0 ;<50 \%=$ poor $; 50 \%-<75 \%=$ moderate $; 75$ and more $=$ good .

\subsection{Analysis of data}

Collected data was revised and coded for computerized data entry. Data were then verified prior to statistical analysis. Statistical methods were applied including descriptive statistics such as (frequency, percentage, ANOVA and $\chi^{2}$ ) were used. $p$-values were considered statistically significant when they were less than .05 .

Table 2 shows the personal data of the studied nurses in Assiut Child Hospital. Regarding age of the studied nurses, it was observed that $43.2 \%$ of them aged $<24$ years, while
$47.7 \%$ of them had $<5$ years of experience. According to their qualifications, $79.5 \%$ of them had secondary school degree.

Table 2. Personal data of the studied nurses in Assiut Child Hospital, 2014

\begin{tabular}{lll}
\hline Items & No. $(\mathbf{n}=\mathbf{4 4})$ & \% \\
\hline Age & 19 & \\
$\quad<24$ years & 9 & 43.2 \\
24-28 years & 5 & 20.4 \\
29-33 years & 11 & 11.4 \\
$\geq 34$ years & & 25.0 \\
Years of experience & 21 & \\
$\quad<5$ years & 10 & 47.7 \\
5-10 years & 13 & 22.7 \\
$>10$ years & & 29.5 \\
Attending training courses & & \\
$\quad$ Yes & 24 & 54.5 \\
$\quad$ No & 20 & 45.5 \\
Qualifications & & \\
Baccalaureate degree & 9 & 79.5 \\
$\quad$ Secondary school degree & 35 & \\
\hline
\end{tabular}


Table 3. Nurses' knowledge regarding febrile seizure throughout intervention program phases, Assiut Children Hospital, 2014

\begin{tabular}{|c|c|c|c|c|c|c|c|}
\hline \multirow{2}{*}{ Items } & \multicolumn{2}{|l|}{ Pre } & \multicolumn{2}{|l|}{ Post } & \multicolumn{2}{|c|}{ Follow up } & \multirow{2}{*}{$p$-value } \\
\hline & No. & $\%$ & No. & $\%$ & No. & $\%$ & \\
\hline \multicolumn{8}{|l|}{ Knowledge concerning the disease } \\
\hline a-Definition of febrile seizure & 8 & 18.2 & 34 & 77.3 & 23 & 52.3 & $.001 * *$ \\
\hline \multicolumn{8}{|l|}{ b-Classifications of febrile seizure } \\
\hline Simple & 6 & 13.6 & 5 & 11.4 & 1 & 2.3 & $.002 * *$ \\
\hline Complex & 9 & 20.5 & 1 & 2.3 & 3 & 6.8 & \\
\hline \multicolumn{8}{|l|}{ c-Manifestations of febrile seizure } \\
\hline Fever & 37 & 84.1 & 40 & 97.7 & 40 & 97.7 & .508 \\
\hline Disturbance in Consciousness & 26 & 59.1 & 36 & 81.8 & 32 & 72.7 & .060 \\
\hline Perception & 5 & 11.4 & 23 & 52.3 & 14 & 31.8 & $.001^{* *}$ \\
\hline Behaviors & 7 & 15.9 & 28 & 63.6 & 24 & 54.5 & $.001^{* *}$ \\
\hline Sensation & 18 & 40.9 & 29 & 65.9 & 28 & 63.6 & $.032 *$ \\
\hline Involuntary movements & 39 & 88.6 & 40 & 90.9 & 36 & 81.8 & .416 \\
\hline \multicolumn{8}{|l|}{ Knowledge concerning nurses' role during febrile seizure } \\
\hline 1) Determine seizure duration. & 17 & 38.6 & 40 & 90.9 & 33 & 75.0 & $.001 * *$ \\
\hline 2) Do not attempt to restrain child. & 23 & 52.3 & 38 & 86.4 & 34 & 77.3 & $.001 * *$ \\
\hline 3) Place small cushion or blanket under child's head. & 10 & 22.7 & 26 & 59.1 & 22 & 50.0 & $.002 * *$ \\
\hline 4) Do not put anything in child's mouth. & 22 & 50.0 & 37 & 84.1 & 29 & 65.9 & $.003 * *$ \\
\hline 5) Remove eyeglasses if present. & 3 & 6.8 & 18 & 40.9 & 18 & 40.9 & $.001^{* *}$ \\
\hline 6) Loosen clothes. & 25 & 56.8 & 24 & 54.5 & 22 & 50.0 & .808 \\
\hline 7) Prevent child from hitting head on sharp objects. & 18 & 40.9 & 31 & 70.5 & 24 & 54.5 & $.020^{*}$ \\
\hline 8) Remove hazards (furniture). & 11 & 25.0 & 29 & 65.9 & 28 & 63.6 & $.001 * *$ \\
\hline 9) Pad objects such as: side rails. & 5 & 11.4 & 19 & 43.2 & 16 & 36.4 & $.003^{* *}$ \\
\hline 10) Keep side rails raised when child is sleeping. & 24 & 54.5 & 25 & 56.8 & 27 & 61.4 & .805 \\
\hline 11) No interference during seizure attack. & 10 & 22.7 & 23 & 52.3 & 17 & 38.6 & $.017^{*}$ \\
\hline 14) Use non pharmacological methods for decrease body temperature. & 27 & 61.4 & 42 & 95.5 & 39 & 88.6 & $.001^{* *}$ \\
\hline 15) Give medication as doctor's prescriptions. & 43 & 97.7 & 44 & 100.0 & 41 & 93.2 & .165 \\
\hline \multicolumn{8}{|l|}{ Knowledge concerning nurses' role after febrile seizures } \\
\hline Determine postictal duration. & 17 & 38.6 & 39 & 88.6 & 32 & 72.7 & $.001 * *$ \\
\hline Maintain child in a side position. & 17 & 38.6 & 35 & 79.5 & 36 & 81.8 & $.001^{* *}$ \\
\hline Use non pharmacological methods for decrease body temperature. & 28 & 63.6 & 36 & 81.8 & 35 & 79.5 & $.100 \mathrm{~ns}$ \\
\hline Give antipyretic medication as doctor's prescriptions. & 41 & 93.2 & 43 & 97.7 & 40 & 90.9 & $.394 n s$ \\
\hline \multicolumn{8}{|l|}{ Knowledge concerning indication for call EMS if } \\
\hline Child stops breathing. & 30 & 68.2 & 38 & 86.4 & 36 & 81.8 & $.095 n s$ \\
\hline There is evidence of injury. & 21 & 47.7 & 26 & 59.1 & 24 & 54.5 & $.491 \mathrm{~ns}$ \\
\hline Seizure lasts for more than 5 minutes. & 14 & 31.8 & 35 & 79.5 & 31 & 70.5 & $.001^{* *}$ \\
\hline Status epilepticus occurs. & 2 & 4.5 & 28 & 63.6 & 25 & 56.8 & $.001 * *$ \\
\hline Child vomits continuously30minutes after seizure has ended. & 19 & 43.2 & 32 & 72.7 & 33 & 75.0 & $.003^{* *}$ \\
\hline $\begin{array}{l}\text { Child cannot be a wakened and is unresponsive to pain after seizure has } \\
\text { ended. }\end{array}$ & 26 & 59.1 & 36 & 81.8 & 34 & 77.3 & $.040 *$ \\
\hline This is child's first seizure. & 17 & 38.6 & 32 & 72.7 & 36 & 81.8 & $.001^{* *}$ \\
\hline \multicolumn{8}{|l|}{ Knowledge concerning febrile seizures precautions } \\
\hline Observe for child's body temperature to early detection for hyperthermia. & 24 & 54.5 & 38 & 86.4 & 41 & 93.2 & $.001 * *$ \\
\hline $\begin{array}{l}\text { Reduce body temperature when hyperthermia by encourage the child to } \\
\text { drink cool fluids. }\end{array}$ & 14 & 31.8 & 22 & 50.0 & 26 & 59.1 & $.033^{*}$ \\
\hline $\begin{array}{l}\text { If hyperthermia occurs remove the child's clothing and apply cold } \\
\text { compresses to the face and neck and sponge the rest of the body with cool } \\
\text { water. }\end{array}$ & 24 & 54.5 & 34 & 77.3 & 32 & 72.7 & $.081 \mathrm{~ns}$ \\
\hline $\begin{array}{l}\text { Give the usual dose of oral fever-reducing medicines (as doctor's } \\
\text { prescriptions) for the hyperthermic child. }\end{array}$ & 35 & 79.5 & 40 & 90.9 & 39 & 88.6 & $.300 \mathrm{~ns}$ \\
\hline
\end{tabular}


Table 3 indicates nurses' knowledge regarding FC throughout intervention program phases; it was observed that $18.2 \%$ of nurses had knowledge about FC before the educational program while $77.3 \%$ of them had knowledge after the program application. Concerning their knowledge about classification of FC before the educational program, it was found that $13.6 \%, 20.5 \%$ and $45.5 \%$ of them had knowledge about classification. So, it was found that there are statistical significant differences between pre, post and follow-up in referring to nurses' knowledge about definition and classifications of FC.

In referring to nurses' knowledge about their role during $\mathrm{FC}$, it was noticed that before application of the program $38.6 \%, 52.3 \%, 22.7 \%, 50.0 \%, 6.8 \%$ of them had knowledge about; determine seizure duration, do not attempt to restrain child, place small cushion or blanket under child's head, do not put anything in child's mouth and remove eyeglasses if present respectively. While after the application of the program $90.9 \%, 86.4 \%, 59.1 \%, 84.1 \%$ and $40.9 \%$ respectively of them had knowledge about their role during FC.
In referral to their knowledge about their roles after FC, it was found that $38.6 \%$ of the studied nurses had knowledge about determine postictal duration and maintain child in a side position. While these improved after the program to be $88.6 \%$ and $79.5 \%$. As regarding to nurses' knowledge about F.C precautions; it was found that before the program $54.5 \%$ and $31.8 \%$ of nurses had knowledge about observing for child's body temperature to early detection for hyperthermia and reducing body temperature when hyperthermia by encourage the child to drink cool fluids, compared with $86.4 \%$ and $50.0 \%$ after the program.

Table 4 shows nurse's performance about febrile seizure throughout intervention program phases, it was found that nurses' role during the attack improved after the intervention program. While there are no statistical significant differences in accordance to turning the child to side in case of vomiting, removing the eyeglasses and loosening the child's clothes $36.4 \%, 9.1 \%$ and $45.5 \%$ compared with $31.8 \%, 22.7 \%$ and $63.6 \%$ respectively after the application of the program.

Table 4. Nurse's performance about febrile seizure throughout intervention program phases, Assiut Children Hospital, 2014

\begin{tabular}{|c|c|c|c|c|c|c|c|}
\hline \multirow{2}{*}{ Items } & \multicolumn{2}{|c|}{ Pre $(n=44)$} & \multicolumn{2}{|c|}{ Post $(n=44)$} & \multicolumn{2}{|c|}{ Follow up $(n=44)$} & \multirow{2}{*}{$p$-value } \\
\hline & No. & $\%$ & No. & $\%$ & No. & $\%$ & \\
\hline \multicolumn{8}{|l|}{ Nursing role during febrile seizure } \\
\hline 1) Determine seizure duration. & 16 & 36.4 & 34 & 77.3 & 33 & 75.0 & $.001^{* *}$ \\
\hline 2) Do not attempt to restrain child. & 27 & 61.4 & 42 & 95.5 & 43 & 97.7 & $.001^{* *}$ \\
\hline 3) Place small cushion or blanket under child's head. & 3 & 6.8 & 7 & 15.9 & 11 & 25.0 & $.066 \mathrm{~ns}$ \\
\hline 4) Do not put anything in child's mouth. & 24 & 54.5 & 40 & 90.9 & 39 & 88.6 & $.001 * *$ \\
\hline 5) Remove eyeglasses if present. & 4 & 9.1 & 10 & 22.7 & 7 & 15.9 & $.217 \mathrm{~ns}$ \\
\hline 6) Loosen clothes. & 20 & 45.5 & 28 & 63.6 & 21 & 47.7 & $.177 \mathrm{~ns}$ \\
\hline 7) Prevent child from hitting head on sharp objects. & 10 & 22.7 & 21 & 47.7 & 12 & 27.3 & $.029 *$ \\
\hline 8) Remove hazards (furniture). & 11 & 25.0 & 25 & 56.8 & 19 & 43.2 & $.010^{* *}$ \\
\hline 9) Pad objects such as: side rails. & 2 & 4.5 & 11 & 25.0 & 6 & 13.6 & $.024 *$ \\
\hline 10) Keep side rails raised when child is sleeping. & 16 & 36.4 & 23 & 52.3 & 10 & 22.7 & $.016^{*}$ \\
\hline 11) No interference during seizure attack. & 20 & 45.5 & 38 & 86.4 & 40 & 90.9 & $.001^{* *}$ \\
\hline 12) Position child with head in mid-line. & 10 & 22.7 & 11 & 25.0 & 9 & 20.5 & $.879 n s$ \\
\hline 13) Turn child to side in case of vomiting. & 16 & 36.4 & 14 & 31.8 & 11 & 25.0 & $.511 \mathrm{~ns}$ \\
\hline $\begin{array}{l}\text { 14) Use non pharmacological methods for decrease } \\
\text { body temperature. }\end{array}$ & 22 & 50.0 & 39 & 88.6 & 37 & 84.1 & $.001^{* *}$ \\
\hline 15) Give medication as doctor's prescriptions. & 43 & 97.7 & 44 & 100.0 & 38 & 86.4 & $.009 * *$ \\
\hline \multicolumn{8}{|l|}{ Nursing role after febrile seizure } \\
\hline Determine postictal duration. & 15 & 34.1 & 37 & 84.1 & 32 & 72.7 & $.001^{* *}$ \\
\hline Maintain child in a side position. & 10 & 22.7 & 33 & 75.0 & 26 & 59.1 & $.001^{* *}$ \\
\hline $\begin{array}{l}\text { Use non pharmacological methods for decrease body } \\
\text { temperature. }\end{array}$ & 19 & 43.2 & 29 & 65.9 & 20 & 45.5 & $.141 \mathrm{~ns}$ \\
\hline Give antipyretic medication as doctor's prescriptions. & 42 & 95.5 & 42 & 95.5 & 39 & 88.6 & $.342 \mathrm{~ns}$ \\
\hline
\end{tabular}

Note. Chi-square test used to obtain $p$ value; $*$ Statistically significant difference $(p$ level $<.05)$; ${ }^{* *}$ Statistically significant difference $(p$ level $<.01)$; Ns: No statistically significant difference ( $p$ level $>.05)$. 
As regarding to their role after the attack, there are improvement in their performance in determining the postictal duration and maintain the child in a side position, compared with no improvement in the practice of using of nonpharmacological drug methods for decrease body temperature and giving antipyretic drug as doctor's prescriptions $p$-value $.001, .001, .141$ and .342 respectively.
Figure 1 shows the total score of nurse's knowledge and practice during pre, post and follow up, it indicates that there is improvement in nurses and performance after intervention of the educational program; $18.9 \%, 30.2 \%$ and $27.6 \%$ for nurses' knowledge and $7.5 \%, 16 \%$ and $14.3 \%$ respectively for the nurses' practices.

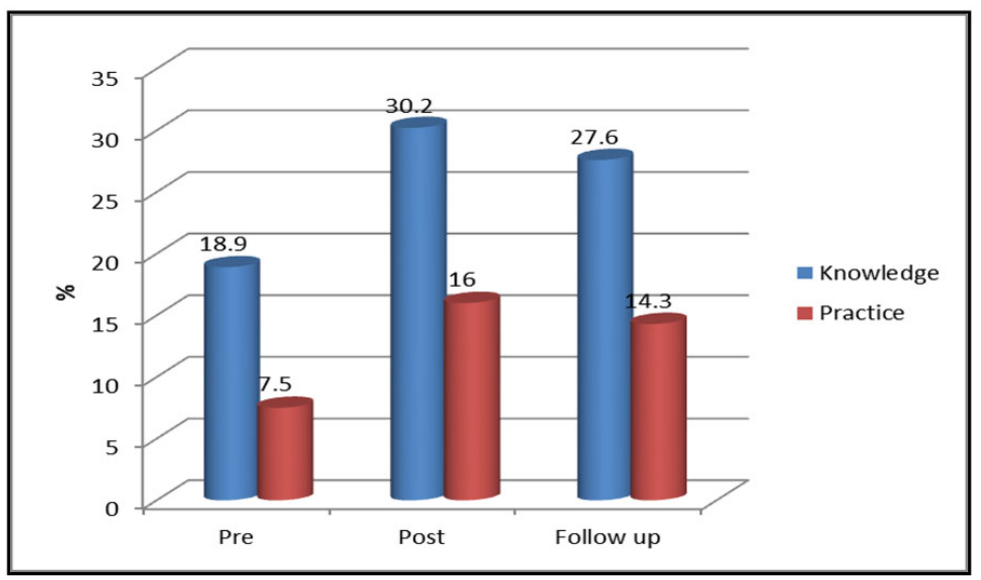

Figure 1. Total score of nurse's knowledge and practice during pre, post and follow up, Assiut Children Hospital, 2014

Table 5 shows comparison between total nurse's knowledge $=.013$. and practice among pre, post and follow up, it was noticed that there is statistical significant difference between nurses' knowledge and practices after post-test and follow-up.

Table 6 shows the relationship between nurse's knowledge and their characteristics during pre, post and follow up; there is statistical differences between nurses' knowledge and their history of attending training courses $p$-value $=.001$.

Table 7 indicates the relationship between nurse's performance and their characteristics during pre, post and follow up; there is statistical differences between nurses' performance and their history of attending training courses $p$-value

\section{Discussion}

FC presents the most common problem in pediatric neurology. Occurring in childhood after age one month associated with a febrile illness not caused by an infection of the CNS, without previous neonatal seizures or a previous unprovoked seizure and not meeting criteria for other acute symptomatic seizures characteristics. The typical febrile convulsion is a generalized tonic clonic seizure lasting between a few seconds and 15 minutes, followed by a period of drowsiness. ${ }^{[12,13]}$

Table 5. Comparison between total nurse's knowledge and practice among pre, post and follow up in Assiut Children Hospital, 2014

\begin{tabular}{|c|c|c|c|c|c|c|c|}
\hline \multirow{2}{*}{ Items } & \multicolumn{2}{|l|}{ Pre } & \multicolumn{2}{|l|}{ Post } & \multicolumn{2}{|c|}{ Follow up } & \multirow{2}{*}{$p$-value } \\
\hline & No. & $\%$ & No. & $\%$ & No. & $\%$ & \\
\hline \multicolumn{8}{|l|}{ Knowledge } \\
\hline Poor & 23 & 52.3 & 3 & 7.1 & 10 & 22.7 & $<.001^{* *}$ \\
\hline Moderate & 21 & 47.7 & 15 & 35.7 & 14 & 31.8 & \\
\hline Good & 0 & 0.0 & 24 & 57.1 & 20 & 45.5 & \\
\hline \multicolumn{8}{|l|}{ Practice } \\
\hline Poor & 29 & 65.9 & 8 & 18.2 & 9 & 20.5 & $<.001^{* *}$ \\
\hline Moderate & 13 & 29.5 & 14 & 31.8 & 16 & 36.4 & \\
\hline Good & 2 & 4.5 & 22 & 50.0 & 19 & 43.2 & \\
\hline
\end{tabular}

Note. ANOVA test used to obtain $p$ value flowed by SLD for multiple comparisons; ${ }^{* *}$ Statistically significant difference $(p$ level $<.01)$. 
Table 6. Relationship between nurse's knowledge and their characteristics during pre, post and follow up in Assiut Children Hospital, 2014

\begin{tabular}{|c|c|c|c|c|c|c|c|c|c|c|c|c|c|c|c|c|c|c|c|c|c|}
\hline & \multicolumn{6}{|c|}{ knowledge before program } & \multirow{4}{*}{$p$} & \multicolumn{6}{|c|}{ knowledge post program } & \multirow{3}{*}{$p$} & \multicolumn{6}{|c|}{ knowledge follow up } & \multirow{3}{*}{$p$} \\
\hline & \multirow{2}{*}{\multicolumn{2}{|c|}{$\begin{array}{l}\text { Poor } \\
\text { No. \% }\end{array}$}} & \multicolumn{4}{|c|}{ Moderate Good } & & \multicolumn{2}{|c|}{ Poor } & \multicolumn{4}{|c|}{ ModerateGood } & & \multirow{2}{*}{\multicolumn{2}{|c|}{$\begin{array}{l}\text { Poor } \\
\text { No. \% }\end{array}$}} & \multicolumn{4}{|c|}{ Moderate Good } & \\
\hline & & & No & $\%$ & & $\%$ & & No. & $\%$ & No. & $\%$ & No. & $\%$ & & & & No. & $\%$ & No. & & \\
\hline \multicolumn{21}{|l|}{ Age } & \\
\hline$<24$ years & 8 & 34.8 & 11 & 52.4 & 0 & 0.0 & \multirow{4}{*}{.350} & 0 & 0.0 & 6 & 40.0 & 13 & 50.0 & \multirow{4}{*}{.330} & 1 & 11.1 & 6 & 42.9 & 12 & 57.1 & \multirow{4}{*}{.081} \\
\hline $24-28$ years & 6 & 26.1 & 3 & 14.3 & 0 & 0.0 & & 2 & 66.7 & 2 & 13.3 & 5 & 19.2 & & 2 & 22.2 & 4 & 28.6 & 3 & 14.3 & \\
\hline 29-33 years & 4 & 17.4 & 1 & 4.8 & 0 & 0.0 & & 0 & 0.0 & 3 & 20.0 & 2 & 7.7 & & 3 & 33.3 & 2 & 14.3 & 0 & 0.0 & \\
\hline$\geq 34$ years & 5 & 21.7 & 6 & 28.6 & 0 & 0.0 & & 1 & 33.3 & 4 & 26.7 & 6 & 23.1 & & 3 & 33.3 & 2 & 14.3 & 6 & 28.6 & \\
\hline \multicolumn{22}{|l|}{ Years of experience } \\
\hline$<5$ years & 10 & 43.5 & 11 & 52.4 & 0 & 0.0 & \multirow{3}{*}{.805} & 1 & 33.3 & 7 & 46.7 & 13 & 50.0 & \multirow{3}{*}{.973} & 2 & 22.2 & 7 & 50.0 & 12 & 57.1 & \multirow{3}{*}{.334} \\
\hline 5-10 years & 6 & 26.1 & 4 & 19.0 & 0 & 0.0 & & 1 & 33.3 & 3 & 20.0 & 6 & 23.1 & & 2 & 22.2 & 4 & 28.6 & 4 & 19.0 & \\
\hline$>10$ years & 7 & 30.4 & 6 & 28.6 & 0 & 0.0 & & 1 & 33.3 & 5 & 33.3 & 7 & 26.9 & & 5 & 55.6 & 3 & 21.4 & 5 & 23.8 & \\
\hline \multicolumn{22}{|l|}{ Qualification } \\
\hline Baccalaureate degree & 2 & 8.7 & 7 & 33.3 & 0 & 0.0 & \multirow{2}{*}{$.043^{*}$} & 0 & 0.0 & 2 & 13.3 & 7 & 26.9 & \multirow{2}{*}{.385} & 0 & 0.0 & 4 & 28.6 & 5 & 23.8 & \multirow{2}{*}{.220} \\
\hline Secondary school degree & 21 & 91.3 & 14 & 66.7 & 0 & 0.0 & & 3 & 100.0 & 13 & 86.7 & 19 & 73.1 & & 9 & 100.0 & 10 & 71.4 & 16 & 76.2 & \\
\hline \multicolumn{22}{|l|}{ Attending training courses } \\
\hline Yes & 7 & 30.4 & 17 & 81.0 & 0 & 0.0 & \multirow{2}{*}{$.001^{* *}$} & 0 & 0.0 & 8 & 53.3 & 16 & 61.5 & \multirow{2}{*}{.127} & 2 & 22.2 & 7 & 50.0 & 15 & 71.4 & \multirow{2}{*}{$.042 *$} \\
\hline No & 16 & 69.6 & 4 & 19.0 & 0 & 0.0 & & 3 & 100.0 & & 46.7 & 10 & 38.5 & & 7 & 77.8 & 7 & 50.0 & 6 & 28.6 & \\
\hline
\end{tabular}

Note. Chi-square test used to obtain $p$ value; $*$ Statistically significant difference $(p$ level $<.05)$; ** Statistically significant difference $(p$ level $<.01)$; Ns: No statistically significant difference ( $p$ level $>.05$ ).

Table 7. Relationship between nurse's performance and their characteristics during pre, post and follow up in Assiut Children Hospital, 2014

\begin{tabular}{|c|c|c|c|c|c|c|c|c|c|c|c|c|c|c|c|c|c|c|c|c|c|}
\hline \multirow{3}{*}{ Characteristics } & \multicolumn{6}{|c|}{ Performance before program } & \multirow{3}{*}{$p$} & \multicolumn{6}{|c|}{ Performance post program } & & \multicolumn{6}{|c|}{ Performance follow up } & \multirow{3}{*}{$p$} \\
\hline & \multirow{2}{*}{\multicolumn{2}{|c|}{$\begin{array}{l}\text { Poor } \\
\text { No. } \% \\
\end{array}$}} & \multicolumn{2}{|c|}{ Moderate } & \multicolumn{2}{|c|}{ Good } & & \multicolumn{2}{|c|}{ Poor } & \multicolumn{2}{|c|}{ Moderate } & \multicolumn{2}{|c|}{ Good } & \multirow[t]{2}{*}{$p$} & \multicolumn{2}{|c|}{ Poor } & \multicolumn{2}{|c|}{ Moderate } & \multicolumn{2}{|c|}{ Good } & \\
\hline & & & No. & $\%$ & No. & $\%$ & & $\overline{\text { No. }}$ & $\%$ & No. & $\%$ & No. & $\%$ & & $\overline{\text { No. }}$ & $\%$ & No. & $\%$ & No. & $\%$ & \\
\hline \multicolumn{22}{|l|}{ Age } \\
\hline$<24$ years & 11 & 37.9 & 7 & 53.8 & 1 & 50.0 & \multirow{4}{*}{.333} & 2 & 25.0 & 4 & 28.6 & 13 & 59.1 & \multirow{4}{*}{.368} & 2 & 22.2 & 4 & 26.7 & 13 & 65.0 & \multirow{4}{*}{.136} \\
\hline $24-28$ years & 7 & 24.1 & 1 & 7.7 & 1 & 50.0 & & 3 & 37.5 & 3 & 21.4 & 3 & 13.6 & & 2 & 22.2 & 3 & 20.0 & 4 & 20.0 & \\
\hline 29-33 years & 5 & 17.2 & 0 & 0.0 & 0 & 0.0 & & 1 & 12.5 & 3 & 21.4 & 1 & 4.5 & & 2 & 22.2 & 3 & 20.0 & 0 & 0.0 & \\
\hline$>34$ years & 6 & 20.7 & 5 & 38.5 & 0 & 0.0 & & 2 & 25.0 & 4 & 28.6 & 5 & 22.7 & & 3 & 33.3 & 5 & 33.3 & 3 & 15.0 & \\
\hline \multicolumn{22}{|l|}{ Years of experience } \\
\hline$<5$ years & 12 & 41.4 & 7 & 53.8 & 2 & 100.0 & \multirow{3}{*}{.529} & 2 & 25.0 & 6 & 42.9 & 13 & 59.1 & & 3 & 33.3 & 5 & 33.3 & 13 & 65.0 & \multirow{3}{*}{.275} \\
\hline $5-10$ years & 8 & 27.6 & 2 & 15.4 & 0 & 0.0 & & 4 & 50.0 & 2 & 14.3 & 4 & 18.2 & .197 & 2 & 22.2 & 4 & 26.7 & 4 & 20.0 & \\
\hline$>10$ years & 9 & 31.0 & 4 & 30.8 & 0 & 0.0 & & 2 & 25.0 & 6 & 42.9 & 5 & 22.7 & & 4 & 44.4 & 6 & 40.0 & 3 & 15.0 & \\
\hline \multicolumn{22}{|l|}{ Qualification } \\
\hline Baccalaureate degree & 4 & 13.8 & 3 & 23.1 & 2 & 100.0 & \multirow{2}{*}{$.013^{*}$} & 1 & 12.5 & 1 & 7.1 & 7 & 31.8 & \multirow{2}{*}{$.167^{3}$} & 3 & 33.3 & 0 & 0.0 & 6 & 30.0 & \multirow{2}{*}{.052} \\
\hline Secondary school degree & 25 & 86.2 & 10 & 76.9 & 0 & 0.0 & & 7 & 87.5 & 13 & 92.9 & 15 & 68.2 & & 6 & 66.7 & 15 & 100.0 & 14 & 70.0 & \\
\hline \multicolumn{22}{|l|}{ Attending training courses } \\
\hline Yes & 13 & 44.8 & 11 & 84.6 & 0 & 0.0 & \multirow{2}{*}{$.016^{*}$} & 5 & 62.5 & 5 & 35.7 & 14 & 63.6 & 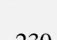 & 5 & 55.6 & 5 & 33.3 & 14 & 70.0 & \\
\hline No & 16 & 55.2 & 2 & 15.4 & 2 & 100.0 & & 3 & 37.5 & 9 & 64.3 & 8 & 36.4 & .230 & 4 & 44.4 & 10 & 66.7 & 6 & 30.0 & .098 \\
\hline
\end{tabular}

Note. Chi-square test used to obtain $p$ value; * Statistically significant difference $(p$ level $<.05)$; ** Statistically significant difference $(p$ level $<.01)$; Ns: No statistically significant difference $(p$ level $>$ 05).

FC is the most common type of seizure in children. They are generally of excellent prognosis. It has become generally accepted that seizures known to be symptomatic of an underlying infection should not be called febrile convulsions. It is an epileptic seizure occurring in childhood after age one month, associated with a febrile illness not caused by an infection of the CNS, without previous neonatal seizures or a previous unprovoked seizure and not meeting criteria for other acute symptomatic seizures. ${ }^{[14,15]}$
According to nurses' knowledge about febrile convulsion through pre, post and follow-up, it was found that there was improvement in the nurses' knowledge about definition of febrile convulsion after the educational program and followup $p$-value .001 . Many of the participated nurses due to their educational qualifications may didn't have the adequate knowledge regarding this point, but their knowledge improved after the educational program and also during period of follow-up. 
Recently, clinicians have begun classifying FS as either simple or complex. Simple FS is defined as generalized, lasting less than 15 minutes, comprised of generalized tonic and clonic activity without a focal component, and without recurrence within 24 hours or within the same febrile illness. Complex or complicated FS is defined as exhibiting one or more of the following features: Partial onset or focal features; prolonged duration of more than 15 minutes; recurrent febrile seizure within 24 hours of the first episode and association with postictal neurological abnormalities. ${ }^{[16,17]}$

In referral to the nurses' knowledge regarding classifications of febrile convulsions, there was improvement in knowledge about both types of febrile convulsion after post and followup of educational program $p$-value .002 .

A seizure is an abnormal and excessive discharge of neurons in the brain involving hyper-synchrony (many neurons firing simultaneously). There may be clinical behavioral changes such as: the child/infant often presenting with impaired consciousness and rhythmic jerking of the extremities, other symptoms may include: Sudden tightening (contractions) of muscles on both sides of the body, crying or moaning, falling if standing, vomiting or biting of tongue, sometimes the child may not breath and begin to turn blue, rhythmic jerking and no response to external voices, the passing of urine and feces. Less commonly, the child becomes rigid or has twitches in only a portion of the body such as an arm or a leg, or on the right or the left side of the body. ${ }^{[18,19]}$

According to nurses' knowledge about manifestations of febrile convulsion, it was found that there aren't statistical significance differences in nurses' knowledge about fever, disturbance in consciousness and involuntary movements $p$ values: .508, .060 and .416 respectively, during pre, post and follow-up. While, there are improvement in their knowledge about perception, behaviors, sensation and posture, $p$-values: $.001, .001, .032$ and .005 respectively regarding manifestations of febrile convulsion.

Initial nursing assessment and management is aimed at maintaining oxygenation and minimizing the risk of complications. The nurse must remain with the child and family and ensure that oxygen, suction and resuscitation equipment are readily accessible. ${ }^{[20]}$

The child should be placed in a semi-prone position and protected from any additional injury. It is imperative that the nurse observe, assess and document the presenting characteristics of the febrile convulsion: Assess the child's color, continuous assessment of vital signs including pulse oximetry, accurate timing of the febrile convulsion, note for alterations in consciousness and document motor sensory and autonomic function, as soon as is appropriate record the Published by Sciedu Press child's temperature, if possible remove warm clothing and pharmacological and non-pharmacological methods of temperature regulation. ${ }^{[20-22]}$

Regarding the nurses' roles during the attack of convulsion, there were statistical significance differences in referral to determine seizure duration, do not attempt to restrain child, place small cushion or blanket, do not put anything in child's mouth, $p$-values: .001, .001, .002, 0.003, respectively, while there aren't statistical significant differences in referral to loosen clothes, keep side rails raised, turn child to side in case of vomiting and give medication as doctor's order, $p$ values: $.808, .805, .674$ and .165 respectively through pre, post and follow-up after educational program.

Nurses' performances during pre, post and follow up revealed that there are improvement in referral to the following practices determine seizure duration, do not attempt to restrain child, do not put anything in child's mouth, prevent child from hitting, remove hazards, keep side rails raised, $p$-values: .001, .001, .001, .029, .010 and .024 respectively, while there no change in their practices regarding place small cushion or blanket under child's head, remove eyeglasses, loosen clothes and turn child to side in case of vomiting, $p$ values: .066, .217, .177 and .511 respectively during phases of educational program.

Regarding to nurses' performances after febrile seizure, it was observed that there was improvement in their practices regarding to determine postictal duration and maintain child, $p$-values: .001 and .001 , while there isn't statistical significance difference in referral to their practices in using non pharmacological and giving antipyretic $p$-values: .141 and .342 .

The comparison between nurses' knowledge and their practices during their fever management practices with improved knowledge will be in an ideal position to educate the parents of the febrile children in their care, providing an ongoing improvement in the health of these children.

\section{Conclusion}

The nurses' knowledge regarding care of child with FC were poor before application of the program with some unsafe practices. The study results showed a marked improvement of overall knowledge and performance scores after educational intervention. The study emphasis on the importance of enhancing of nurses' knowledge and it's implication on their performance. Also, the study confirms the need for further multifaceted educational training program for improving nurses' management of child with FC.

\section{Conflicts of InTEREST Disclosure}

The authors declare that there is no conflict of interest. 


\section{REFERENCES}

[1] Waruiru C, Appleton R. Febrile seizures: an update. Arch Dis Child. 2013; 89(8): 751-756. PMid:15269077 http://dx.doi.org/10 1136/adc. 2003.028449

[2] American Academy of Pediatrics. Report of the Committee on management and complication of convulsion (26th ed.). Elk Grove Village, III: American Academy of Pediatrics. 2011.

[3] Millar JS. Evaluation, risk factors and treatment of the child with febrile seizure. Am Fam Physician. 2011; 73(10): 1761-1764.

[4] Berg AT, Shinnar S, Shapiro ED, et al. Risk factors for a first febrile seizure: a matched case-control study. Epilepsia. 2012; 36(4): 334-341. http://dx.doi.org/10.1111/j.1528-1157 1995.tb01006. $\mathrm{x}$

[5] Bethune P, Gordon K, Dooley J, et al. Which child will have a febrile seizure? Am J Dis Child. 2010; 147(1): 35-39.

[6] Vaswani RK, Dharaskar PG, Kulkarni S, et al. Risk factor for first febrile seizure. Indian Pediatr. 2010; 47(5): 437-439. PMid:19736364 http://dx.doi.org/10.1007/s13312-010-0080-8

[7] Vestergaard M, Hviid A, Madsen KM. Classification of febrile seizures: Evaluation of susceptible subgroups and long-term prognosis. JAMA. 2010; 292(3): 351-357. PMid:15265850 http://dx.d oi.org/10.1001/jama.292.3.351

[8] Demicheli V, Jefferson T, Rivetti A, et al. History of epilepsy and f.c.in children. Cochrane Database Syst Rev. 2011.

[9] Ganesh R, Janakiraman L. Serum levels in children with simple febrile seizure. Clin Pediatr (Phila). 2012; 47(2): 164 166. PMid:17873242 http://dx.doi.org/10.1177/000992280 7306165

[10] Hartfield DS, Tan J, Yager JY. The management of febrile seizures in childhood. Clin Pediatr (Phila). 2014; 48(4): 420426. PMid:19229063 http://dx.doi .org/10.1177/000992280 9331800

[11] Wong DL, Hockenberg-Eaton M, Winkelstein ML, et al. Nursing Care for Child with febrile seizure, Wally and Wongs Nursing Care of Infant and Children, 9th ed., C.V. Mosby Company ST Louise, Baltimore Philadelphia and Toronto, Chapter; 2013; 37: 1807-1830.

[12] Mahmood KT, Fareed T, Tabbasum R. Management of febrile seizures in children. Journal of Biomed Science and Research. 2010; 3(1): 353-357.
[13] Graves RC, Oehler K, Tingle LE. Febrile Seizures: Risks, Evaluation, and Prognosis. American Academy of Family Physicians. 2012; 85(2): 150-151.

[14] Al-Ajlouni SF, Kodah IH. Febrile convulsions in children, review articles. Neurosciences. 2000; 5(3): 151-155. PMid:24276802

[15] Verity CM. Febrile convulsions a practical guide, Child Development Centre, Addenbrooke's Hospital, Cambridge. 2015. Available from: https://www.epilepsysociety.org.uk/sites/defau 1t/files/attachments/Chapter08Verity2015.pdf

[16] American Academy of Pediatrics. Clinical practice guideline-febrile seizure: Guideline for the neuro-diagnostic evaluation of the child with a simple febrile seizure. 2011; 127(2): 389-393. Available from: http://pediatrics.aappublications.org/content /pediatrics/127/2/389.full.pdf

[17] Chung S. Febrile seizures. Korean Journal of Pediatric. 2014; 57(9): 384-395. Available from: http://synapse.koreamed . org/Synapse/Data/PDFData/0052KJP/kjp-57-384.pdf PMid:25324864 http://dx.doi.org/10.3345/kjp.2014.57 .9 .384

[18] The American Academy of Pediatrics. Febrile Seizures: Clinical practice guideline for the long-term management of the child with simple febrile seizures. 2008. 121, 1281-1286.

[19] Raissi E, Sinclair B, Lewis M. Febrile Seizures. 2014. 1-8 p. Available from: http://www.pedscases.com/sites/default/fi les/Febrile\%20Seizures\%20Script.pdf

[20] Raftery S. Febrile Convulsions: Assessment, treatment and education, World of Irish Nursing. 2002; 10(3): 27-28. Available from: https://www.inmo.ie/Article/PrintArticle/2661

[21] Edwards HE, Courtney MD, Wilson JE, et al. Fever management practices: What pediatric nurses say. Nursing and Health Sciences. 2001; 3(3): 119-130. http://dx.doi.org/10.1046/j.1442-2 $018.2001 .00083 . \mathrm{x}$

[22] George J, Joseph J. A study to assess the effectiveness of structured teaching program regarding knowledge on management of febrile convulsion among mothers of under five children in Rajarajeswari Medical College and Hospital, Bangalore. International Journal of Science and Research (IJSR). 2013; 4 (11): 1070-1074. 